\title{
Growth patterns of preterm infants in Korea
}

Joohee Lim, MD*, So Jin Yoon, MD*, Soon Min Lee, MD, PhD

Department of Pediatrics, Yonsei University College of Medicine, Seoul, Korea

With advancements in neonatal care and nutrition, the postnatal growth of preterm infants has improved; however, it remains an issue. Accurate assessments of growth using a standardized reference are needed to interpret the intrauterine and postnatal growth patterns of preterm infants. Growth in the earlier periods of life can contribute to later outcomes, and the refinement of postnatal growth failure is needed to optimize outcomes. Catchup growth occurs mainly before discharge and until 24 months of age, and very low birth weight infants in Korea achieve retarded growth later in life. Knowing an infant's perinatal history, reducing morbidity rates during admission, and performing regular monitoring after discharge are required. Preterm infants with a lower birth weight or who were small for gestational age are at increased risk of poor neurodevelopmental outcomes. Furthermore, poor postnatal growth is predictive of adverse neurodevelopmental outcomes. Careful monitoring and early intervention will contribute to better development outcomes and national public health improvements.

Key words: Growth, Preterm infants, Development, Growth failure

\section{Key message}

- The growth of preterm infants is a main focus of neonatology.

- Preterm infants in Korea, especially those with a very low birth weight, achieve retarded growth.

- Careful growth monitoring and early intervention will contribute to better development outcomes and quality of life for preterm infants and improve public health.

\section{Introduction}

The recommendation to encourage preterm infants to grow in utero at a rate comparable to that of their age-matched peers is rather clear. However, their postnatal growth often does not achieve this goal. The percentage of infants with severe growth failure has decreased significantly over time. However, such improvements are insufficient. Various studies have examined the growth of preterm infants in Korea; however, few have focused on the data of preterm infants from a large-scale database. With advancements in neonatal care, the survival rates of premature infants in Korea have become comparable to those of medically advanced countries. Therefore, reviewing growth data for premature infants in Korea and comparing them with data from other countries can help improve the long-term growth and development and quality of life of premature infants in Korea.

\section{Growth assessment}

Neonatal growth charts that allow the calculation of precise $z$ scores and percentiles were introduced in neonatology over the past decade. Growth standards are prescriptive and define how a population of children should grow if given optimal nutrition and health. Growth charts (references), on the other hand, describe a child's growth at a certain point in time. Several charts and growth standards for interpreting intrauterine and postnatal growth patterns of infants have been introduced (Table 1), but their comparison is difficult due to age range variability and methodological problems.

Over 50 years ago, Lubchenco constructed the first intrauterine growth chart using birth records from the 1950s representing birth weight for gestational age at 24-42 weeks. ${ }^{1)}$ Olsen growth charts from the United States and Bertino growth charts from Italy assess appropriate for gestational age (AGA), small for gestational age (SGA), and large for gestational age status at a wide gestational age range of 22-23 to 42 weeks. $\left.{ }^{2,3}\right)$ The Olsen growth chart included more diverse ethnicities ${ }^{4}$; however, it is limited because the sample included neonatal intensive care unit (NICU) admissions only, so they are known to perform relatively poor growth monitoring beyond 36 weeks of age.

The Fenton chart introduced fetal and infant growth reference data for 22-50 weeks in 2003. .) It was last updated in 2013 after a meta-analysis of 6 studies monitoring postnatal growth and revised to harmonize and continue using the World Health Organization (WHO) Growth Standard after 50 weeks' postmenstrual age. $\left.{ }^{6}\right)$ However, it did not consider postnatal adaptations, especially by ignoring the physiological fluid loss that occurs in the

Corresponding author: Soon Min Lee, MD, PhD, Department of Pediatrics, Yonsei University College of Medicine, 211 Eonju-ro Gangnam-gu, Seoul 06273, Korea 凶Email: smlee@yuhs.ac, https://orcid.org/0000-0003-0174-1065

*These authors contributed equally to this work

Received: 28 February, 2021, Revised: 27 May, 2021, Accepted: 11 June, 2021

This is an open-access article distributed under the terms of the Creative Commons Attribution Non-Commercial License (http://creativecommons.org/licenses/bync/4.0/) which permits unrestricted non-commercial use, distribution, and reproduction in any medium, provided the original work is properly cited.

Copyright (c) 2022 by The Korean Pediatric Society 


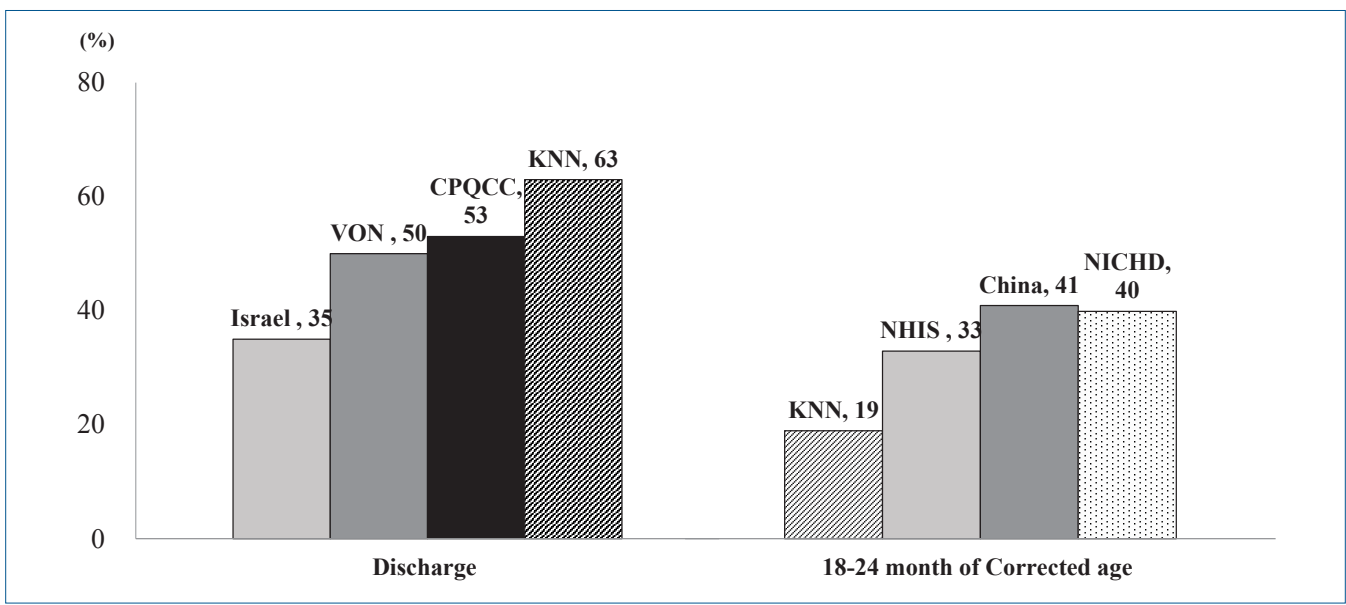

Graphical Abstract. The incidence of poor growth (weight <10 percentile) in preterm infants. VON, Vermont Oxford Network; CPQCC, California Perinatal Quality Care Collaborative; KNN, Korean Neonatal Network; NHIS, national health insurance system in Korea; NICHD, National Institute of Child Health and Human Development.

Table 1. Review of growth charts and standards

\begin{tabular}{|c|c|c|c|c|c|c|c|}
\hline & Olsen chart & Bertino chart & $\begin{array}{c}\text { Fenton } \\
\text { Growth Chart }\end{array}$ & $\begin{array}{l}\text { Intergrowth } \\
\text { Growth Standard }\end{array}$ & $\begin{array}{c}\text { WHO } \\
\text { Growth Standard }\end{array}$ & $\begin{array}{c}\text { CDC } \\
\text { Growth Chart }\end{array}$ & $\begin{array}{l}\text { Korean National } \\
\text { Growth Chart }\end{array}$ \\
\hline History & 2010 & 2010 & $\begin{array}{l}\text { 2003, Updated in } \\
2013\end{array}$ & 2014 & 2006 & 2000 & $\begin{array}{l}\text { 2007, updated in } \\
2017\end{array}$ \\
\hline Data source & $\begin{array}{l}\text { Cross-sectional } \\
\text { sample of birth } \\
\text { data from Pe- } \\
\text { diatrix Medical } \\
\text { Group, Inc }\end{array}$ & $\begin{array}{l}\text { Nationwide pro- } \\
\text { spective study in } \\
\text { Italy }\end{array}$ & $\begin{array}{l}\text { Literature selection } \\
\text { and combination } \\
\text { by University of } \\
\text { Calgary }\end{array}$ & $\begin{array}{l}\text { INTERGROWTH-21st } \\
\text { Consortium ( } 27 \text { in- } \\
\text { stitutions in } 18 \text { co- } \\
\text { untries worldwide } \\
\text { and coordinated } \\
\text { from the University } \\
\text { of Oxford) }\end{array}$ & $\begin{array}{l}\text { WHO multicenter } \\
\text { growth refer- } \\
\text { ence study }\end{array}$ & $\begin{array}{l}\text { National Health Ex- } \\
\text { amination Surveys } \\
\text { and the National } \\
\text { Health and Nutri- } \\
\text { tion Examination } \\
\text { Surveys }\end{array}$ & $\begin{array}{l}\text { Ministry of Health } \\
\text { and Welfare and } \\
\text { the Korean Pedi- } \\
\text { atric Society }\end{array}$ \\
\hline Sample size & 257,855 & $\begin{array}{l}\text { 22,087 Girls and } \\
23,375 \text { boys. }\end{array}$ & Nearly 25000 & Nearly 60,000 & 27,853 & $\begin{array}{l}\text { Birth to } 36 \text { months: } \\
\text { nearly 900,000 } \\
\text { 2-20 years: nearly } \\
32,000\end{array}$ & 252,359 \\
\hline Dates of data & 1998-2006 & $2005-2007$ & $1987-2012$ & 2009-2014 & 1997-2005 & 1963-1994 & 1997-2005 \\
\hline Age range & 22-42 Weeks & 23-42 Weeks & 22-50 Weeks & $\begin{array}{l}>14 \text { Weeks of gesta- } \\
\text { tion to } 2 \text { years of } \\
\text { age }\end{array}$ & Birth-59 months & Birth-20 years & $\begin{array}{l}\text { 3-18 years }(<3 \\
\text { years: WHO grow- } \\
\text { th chart) }\end{array}$ \\
\hline Data & WT, LT, and HC & WT, LT, and HC & WT, HC, LT & $\begin{array}{l}\text { WT, HC, LT according } \\
\text { to GA and sex }\end{array}$ & WT, HC, LT & $\begin{array}{l}\text { Infant: } W T, L T, H C \\
\text { Pediatric: WT, HT, } \\
\text { BMI }\end{array}$ & $\begin{array}{l}\text { WT, HC, LT, BMI, } \\
\text { WT for HT }\end{array}$ \\
\hline $\begin{array}{c}\text { Exclusion } \\
\text { criteria }\end{array}$ & & $\begin{array}{l}\text { Only fetal hydrops } \\
\text { and major con- } \\
\text { genital anomal- } \\
\text { ies diagnosed at } \\
\text { birth }\end{array}$ & $\begin{array}{l}\text { Infants who were } \\
\text { not discharged } \\
\text { from the hospital } \\
\text { at } 50 \text { weeks of } \\
\text { PMA }\end{array}$ & $\begin{array}{l}\text { Maternal smoking, } \\
\text { severe maternal } \\
\text { obesity or morbidity, } \\
\text { congenital malfor- } \\
\text { mations, or ultra- } \\
\text { sound evidence of } \\
\text { fetal growth retar- } \\
\text { dation }\end{array}$ & $\begin{array}{l}\text { Maternal smok- } \\
\text { ing, breastfeed- } \\
\text { ing less than } 3 \\
\text { months }\end{array}$ & $\begin{array}{l}\text { Birth weight }<1,500 \\
\mathrm{~g}\end{array}$ & \\
\hline
\end{tabular}

CDC, Centers for Disease Control and Prevention; WHO, World Health Organization; WT, weight; LT, length; HC, head circumference; GA, gestational age; BMI, body mass index; $H T$, height; PMA, postmenstrual age.

first few days of life.

In 2014, the INTERGROWTH-21st Consortium published international postnatal growth standards for preterm infants 27 64 weeks' postmenstrual age based on neonates with no major complications or risk factors or ultrasound evidence of fetal growth restrictions who were born to healthy mothers. ${ }^{7)}$ The INTERGROWTH-21st is a multicenter multiethnic populationbased project that proposed growth patterns using a representa- tive population sample from 8 geographical areas of the world. It aims to better adapt to premature growth of infants 24-33 weeks' gestation. However, concerns remain that fetal growth parameters may differ among ethnicities and that population-based growth references for infants with the same genetic and environmental backgrounds should be used. ${ }^{8)}$

The Centers for Disease Control and Prevention growth charts for use in children from birth to 20 years were released in May 
2000 based on the National Center for Health Statistics growth chart in 1977 with the addition of more recent comprehensive data and improvements in the statistical smoothing procedure.9) These growth charts were based primarily on nationally representative survey data for healthy infants, excluded very low birth weight (VLBW) infants, were supplemented with limited data from other sources, and used a descriptive approach to generate a reference to describe the distribution of size for age in the United States.

In 2006, the WHO released international growth standards for children aged 0-59 months that are now accepted worldwide. ${ }^{10)}$ These standards include all children regardless of ethnicity and socioeconomic status and include those who were predominantly breastfed for at least 4 months and still breastfeeding at 12 months. However, the WHO growth charts, although recommended for preterm infants after term age, begin at term and do not assist preterm infant growth assessments prior to this age.6)

The Korean National Growth Chart (KNGC) was released in 2017 for the evaluation of body size and growth of Korean children and adolescents in private and public health clinics. ${ }^{11)}$ In children aged 0-35 months, a WHO growth chart was used with the recommendation of breastfeeding as the ideal nutritional supply for infants. For children and adolescents aged 3-18 years, height for age, weight for age, body mass index for age, weight for height, and head circumference (HC) for age charts were developed to overcome the limitations of the KNGC 2007 version.

In Korea, the Fenton growth chart is commonly used to assess preterm growth and promising for optimal preterm growth monitoring. After term-equivalent age is reached, the KNGC is widely used, although it is the same as the WHO chart for children younger than 3 years of age.

\section{Postnatal growth during NICU admission}

Among the 355 published preterm infant growth studies published since 2005, 19\% showed extrauterine growth restriction (EUGR) or postnatal growth failure (PGF) rates mainly defined as being below the 10th percentile (62\%) and the 3rd percentile $(28 \%)$ at the time of discharge (61\%), term (20\%), or 36 weeks' gestation (19\%). ${ }^{12)}$ According to previous reports of various neonatal networks, the rate of PGF among VLBW infants, defined as a discharge weight below the 10th percentile, was noted to exceed 95\% in the 1990s in the National Institute of Child Health and Human Development (NICHD) study, a decreasing trend from 2000 to 2013 (65\% to 50\%) in the Vermont Oxford Network, and 53\% using the Fenton growth chart in 2005-2012 from the California Perinatal Quality Care Collaborative (CPQCC). ${ }^{13,14)}$ In a single-center study of data from the KNGC, $67 \%$ of VLBW infants were admitted between 2005 and 2009 versus 47\% of VLBW infants admitted between 2010 and 2011. ${ }^{15,16)}$ In the Korean Neonatal Network (KNN) study, the weight $z$ score at discharge among surviving 2,799 VLBW infants was -1.37 , showing a greater than 50\% PGF incidence using the Fenton growth chart. ${ }^{17)}$ The incidence of PGF in Korea is comparable to those of other countries.

However, the term PGF requires refinement in the diagnostic criteria because EUGR is not predictive of adverse neurodevelopmental outcomes and is usually used to apply intrauterine growth restriction (IUGR) criteria. ${ }^{18)}$ The definition of malnutrition in preterm infants includes ow growth velocity (weight and length growth), change in weight $z$ score, and previous nutrient intake. When PGF of VLBW was defined as a weight $z$ score decrease from birth to discharge using the Fenton growth chart, the KNN reported that $45.5 \%$ of the infants had a score that exceeded 1.28 , in accordance with the $41 \%$ of infants whose score exceeded 1.0 in the CPQCC. ${ }^{14,17)}$ Among the Israel National VLBW infant database, $8.1 \%$ and $35.5 \%$ had a decrease in $z$ scores of $>2$ and 1-2 using a Canadian reference, respectively. ${ }^{19)}$

The growth of preterm infants is adversely affected by neonatal morbidities such as necrotizing enterocolitis, gastrointestinal perforations, intraventricular hemorrhage, retinopathy of prematurity, and bronchopulmonary dysplasia. In addition, nutritionrelated factors such as enteral feeding and parenteral nutrition practices can be significant risk factors for PGF. ${ }^{20-22)}$ Infants born SGA or with IUGR had poor growth outcomes. ${ }^{17,23)}$ A growth assessment is necessary to elucidate how well an infant's nutritional needs are being met and which infants have difficulty overcoming neonatal morbidities. Recent evidence points to the importance of true growth faltering for optimizing outcomes and supporting infants who are growing adequately to continue on their successful path rather than using a one-time size value at 40 weeks or prior.

It is challenging to further improve our understanding of the growth and nutritional needs of preterm infants during NICU admission. Furthermore, clinical judgment and individualization are needed to set growth goals and assess nutritional status to ensure better outcomes.

\section{Postnatal growth after discharge, especially in VLBW infants}

The incidence of growth failure after discharge is declining, but it has not yet been overcome. Table 2 presents a study of postnatal growth in premature infants after discharge. Research on VLBW infants using the KNGC at a single center in Korea revealed a $33 \%$ rate of weight below the 10th percentile at 24 months in 2000-2001, a 19\% (18 of 98) rate of weight below the 10th percentile at 18 months of postchronological age (PCA) between 1996 and 2000, and a 12.4\% (14 of 113) rate of weight below the 3 rd percentile at 18 months of PCA between 1997 and 1999. ${ }^{24-26)}$ A prospective cohort study of a total of 2,943 VLBW infants from the KNN between 2013 and 2015 showed a rate of $18.5 \%$ at $18-24$ months of corrected age and a rate of $33.5 \%$ at 36 months of age for a weight $\mathrm{z}$ score $<-1.28$ using the WHO growth chart. ${ }^{27)}$ A nationwide study from the Korean National Health Insurance System (NHIS) database showed the rate of poor 
Table 2. Characteristics of the studies included in the review of preterm infant growth after neonatal intensive care unit discharge

\begin{tabular}{|c|c|c|c|c|c|}
\hline Study & $\begin{array}{l}\text { Study design/ } \\
\text { country }\end{array}$ & $\begin{array}{l}\text { Characteristics:Number, } \\
\text { GA/BW, SGA/AGA, }\end{array}$ & Age at follow-up & Measurement & Main results \\
\hline Han et al. ${ }^{28)} 2021$ & $\begin{array}{l}\text { Retrospective, } \\
\text { Korea }\end{array}$ & $\begin{array}{l}2,961 \\
\mathrm{BW}<1,500 \mathrm{~g}\end{array}$ & $\begin{array}{l}4-6,9-12,18-24 \\
30-36,42-48 \text { and } \\
54-60 \text { months }\end{array}$ & $\mathrm{HT}, \mathrm{WT}, \mathrm{HC}$ & $\begin{array}{l}\text { About } 30 \% \text { had growth parameters below the } 10 \text { th } \\
\text { percentile. } \\
\text { Increased growth restriction in Infants with morbidities. }\end{array}$ \\
\hline Yoon et al. ${ }^{35)} 2021$ & $\begin{array}{l}\text { Retrospective, } \\
\text { Korea }\end{array}$ & $\begin{array}{l}430,541 \\
\text { BW subgroup; <1,000 } \\
\text { g, 1,000-1,499 g, } \\
1,500-1,999 \mathrm{~g} \\
2,000-2,499 \mathrm{~g} \\
2,500-4,500 \mathrm{~g}\end{array}$ & $\begin{array}{l}4-6,9-12,18-24 \\
30-36,42-48, \text { and } \\
54-60 \text { months }\end{array}$ & HT, WT, HC & $\begin{array}{l}\text { Higher incidence of poor WT, HT, and HC growth at } 60 \text { mo } \\
\text { in LBW groups. A significant correlation with the growth } \\
\text { measurement at } 60 \text { months and at } 6 \text { months especially } \\
\text { in ELBWs }\end{array}$ \\
\hline Song et al. ${ }^{34)} 2020$ & $\begin{array}{l}\text { Retrospective, } \\
\text { Korea }\end{array}$ & $\begin{array}{l}122 \\
\text { BW }<1,500 \text { g or } G A<32 \\
\text { weeks } \\
\text { SGA } 29 / A G A 93\end{array}$ & $\begin{array}{l}\text { PMA } 35 \text { weeks, } 4 \\
18 \text { months PCA }\end{array}$ & HT, WT, HC & $\begin{array}{l}\text { Decreased mean } z \text { scores of all growth indicators from } \\
\text { birth to PMA } 35 \text { weeks in both groups. From } 4 \text { to } 18 \\
\text { months, the } 3 \text { growth indicators for SGAs continued to } \\
\text { increase }\end{array}$ \\
\hline Park et al. ${ }^{15)} 2017$ & $\begin{array}{l}\text { Retrospective, } \\
\text { Korea }\end{array}$ & $\begin{array}{l}81 \\
\text { VLBW infants } \\
\text { SGA 17/AGA } 64\end{array}$ & $\begin{array}{l}\text { At PCA } 40 \text { weeks, } \\
\text { every } 3 \text { months } \\
\text { until PCA } 24 \\
\text { months }\end{array}$ & HT, WT & $\begin{array}{l}\text { Higher growth failure rates in SGA infants, ELBW infants } \\
\text { at PCA } 24 \text { months. }\end{array}$ \\
\hline Park et al. ${ }^{59)} 2015$ & $\begin{array}{l}\text { Retrospective, } \\
\text { Korea }\end{array}$ & $\begin{array}{l}103 \\
\text { Preterm } \\
\text { SGA 34/AGA } 69\end{array}$ & 12,24 months PCA & WT & $\begin{array}{l}\text { One birth weight } z \text { score decrement increased the odds } \\
\text { for CUG failure (OR=2.9 at } 12 \text { months and } 3.0 \text { at } 24 \\
\text { months). } \\
\text { The increase in z score between } 12-24 \text { months PCA in the } \\
\text { nutritional support group. }\end{array}$ \\
\hline $\begin{array}{l}\text { Ou-Yang et al. } \\
2020\end{array}$ & $\begin{array}{l}\text { Meta-analysis \& } \\
\text { systematic } \\
\text { review }\end{array}$ & $\begin{array}{l}169,439 \\
\text { Children } \\
\text { Preterm/term }\end{array}$ & $\begin{array}{l}\text { Childhood, } \\
\text { adolescent }\end{array}$ & WT, BMI & $\begin{array}{l}\text { Accelerated WT gain during first } 2 \text { years significantly } \\
\text { increased the likelihood of subsequent childhood } \\
\text { obesity among preterms (aOR=1.87) }\end{array}$ \\
\hline $\begin{array}{l}\text { Van de Pol and } \\
\text { Allegaert } \\
2020\end{array}$ & $\begin{array}{l}\text { Systematic re- } \\
\text { view, Belgium }\end{array}$ & $\mathrm{BW}<1,000 \mathrm{~g}$ & $\begin{array}{l}\text { From birth to } \\
\text { adulthood }\end{array}$ & $\begin{array}{l}\text { WT, HT, HC, } \\
\text { BMl }\end{array}$ & $\begin{array}{l}\text { After hospital discharge, ELBW neonates remained with } \\
\text { poor WT, HT, and HC at each CA throughout childhood } \\
\text { and adolescence }\end{array}$ \\
\hline Liao et al. ${ }^{61)} 2019$ & $\begin{array}{l}\text { Prospective, } \\
\text { Taiwan }\end{array}$ & $\begin{array}{l}2,124 \\
\mathrm{GA}<37 \text { weeks and } \\
\mathrm{BW}<1,500 \mathrm{~g}\end{array}$ & $\begin{array}{c}\text { At } 6,12 \text {, and } 24 \\
\text { months PCA }\end{array}$ & WT & $\begin{array}{l}\text { The prevalence of PGF was } 17.3 \%, 19.4 \% \text {, and } 13.8 \% \text { at } \\
\text { the CA of } 6,12 \text {, and } 24 \text { months, respectively. The } \\
\text { significant perinatal factors of PGF were being SGA, } \\
\text { ELBW and EUGR. }\end{array}$ \\
\hline $\begin{array}{l}\text { Lindström et al. }{ }^{43)} \\
2019\end{array}$ & $\begin{array}{l}\text { Prospective, } \\
\text { Sweden }\end{array}$ & $\begin{array}{l}\text { 41,669 } \\
\text { GA 32-40 weeks }\end{array}$ & $1.5,3,4,5$ Years & $\begin{array}{l}\text { WT, HT, HC, } \\
\text { BMl }\end{array}$ & $\begin{array}{l}\text { Those born SGA in GA } 32 \text { weeks or } 35 \text { weeks had poor HT, } \\
\text { WT, mean BMI throughout the whole follow-up period. } \\
\text { The association seemed stronger the shorter GA at birth. }\end{array}$ \\
\hline $\begin{array}{l}\text { Olbertz et al. }{ }^{39)} \\
2019\end{array}$ & $\begin{array}{l}\text { Longitudinal, } \\
\text { Germany }\end{array}$ & $\begin{array}{l}\text { 1,496 term AGA/173 } \\
\text { preterm SGA/891 } \\
\text { term SGA }\end{array}$ & 4 Years & $\begin{array}{l}\text { HT, WT, HC, } \\
\text { BMI }\end{array}$ & $\begin{array}{l}\text { Inferior growth outcome in preterm or full-term born SGA } \\
\text { children from birth until } 3 \text { years. The higher growth } \\
\text { velocity of SGA children in the first } 2 \text { years. }\end{array}$ \\
\hline $\begin{array}{l}\text { Visuthranukul et } \\
\text { al. }^{62)} 2019\end{array}$ & $\begin{array}{l}\text { Prospective, } \\
\text { United States }\end{array}$ & $\begin{array}{l}51 \\
\text { BW } \leq 1,250 \mathrm{~g} \\
\text { SGA 18/AGA } 33\end{array}$ & $\begin{array}{l}\text { At discharge, } 12-15 \text {, } \\
\text { 18-22 months } \\
\text { PCA }\end{array}$ & HT, WT, HC & $\begin{array}{l}\text { SGA premature infants with an exclusive HM-based diet in } \\
\text { NICU until } 34 \text { weeks PCA exhibited greater CUG without } \\
\text { increased adiposity or elevated insulin resistance at } 2 \\
\text { years }\end{array}$ \\
\hline $\begin{array}{l}\text { Toftlund et al. }^{33)} \\
2018\end{array}$ & $\begin{array}{l}\text { Prospective, } \\
\text { Denmark }\end{array}$ & $\begin{array}{l}281 \\
\text { GA } 24-32 \text { weeks } \\
\text { UHM/FHM/PF }\end{array}$ & 6 Years & WT & $\begin{array}{l}\text { CUG occurred mainly before discharge. CUG in UHM-fed } \\
\text { infants was slower, but extended until } 6 \text { years. Rapid } \\
\text { weight growth was most pronounced shortly after } \\
\text { discharge and especially if PF-fed. }\end{array}$ \\
\hline $\begin{array}{l}\text { Raaijmakers et } \\
\text { al. }^{36)} 2017\end{array}$ & $\begin{array}{l}\text { Prospective, } \\
\text { Belgium }\end{array}$ & $\begin{array}{l}140 \\
B W<1,000 \mathrm{~g}\end{array}$ & $\begin{array}{l}\text { At } 9 \text { and } 24 \text { months } \\
\text { and at } 11 \text { years }\end{array}$ & WT, HT, HC & $\begin{array}{l}\text { ELBW children still had HT, WT, HC below target at } 11 \\
\text { years. } \\
\text { CUG in ELBW children in the first } 2 \text { years of life is } \\
\text { associated with a lower percentage body fat and is } \\
\text { therefore likely to be beneficial. }\end{array}$ \\
\hline $\begin{array}{l}\text { Rowe et al. }{ }^{37)} \\
2011\end{array}$ & $\begin{array}{l}\text { Cohort study, } \\
\text { New Zealand }\end{array}$ & $\begin{array}{l}54 \\
<37 \text { weeks, 82: control }\end{array}$ & 2-20 years & HT, WT & $\begin{array}{l}\text { Preterm is shorter and lighter than controls throughout } \\
\text { childhood, remaining below their genetic height } \\
\text { potential. }\end{array}$ \\
\hline $\begin{array}{l}\text { Sullivan et al. } \\
2008\end{array}$ & $\begin{array}{l}\text { Prospective, } \\
\text { United States }\end{array}$ & $\begin{array}{l}148 \\
\text { BW }<1,850 \mathrm{~g} \text { and } 46 \text { full } \\
\text { term/29 preterm SGA }\end{array}$ & $\begin{array}{l}18,30 \text { months CA, } \\
4,8 \text {, and } 12 \text { years }\end{array}$ & WT, HT, BMI & $\begin{array}{l}\text { Only the SGA group had smaller HT at age } 12 \text { years. The } \\
\text { preterm with neurologic illness, and SGA groups had } \\
\text { lower WT through age } 12 \text { years. BMI was appropriate } \\
\text { for preterm groups by age } 4 \text { years. Across time, } \\
\text { neonatal morbidity had a significant effect on HT and } \\
\text { WT trajectories. }\end{array}$ \\
\hline $\begin{array}{l}\text { Farooqi et al. }{ }^{63)} \\
2006\end{array}$ & $\begin{array}{l}\text { Prospective, } \\
\text { Sweden }\end{array}$ & $\begin{array}{l}247 \\
G A<26 \text { weeks }\end{array}$ & $\begin{array}{l}\text { From birth to the } \\
\text { age of } 11 \text { years }\end{array}$ & $\begin{array}{l}\text { WT, HT, HC, } \\
\text { BMl }\end{array}$ & $\begin{array}{l}\text { Sharp decline in WT and HT z scores up to } 3 \text { months' CA, } \\
\text { followed by CUG in both WT and HT up to } 11 \text { years. No } \\
\text { CUG in HC after the first } 6 \text { months. }\end{array}$ \\
\hline
\end{tabular}

GA, gestational age; BW, birth weight; SGA, small for gestational age; AGA, appropriate for gestational age; HT, height; WT, weight; HC, head circumference; LBW, low birth weight; ELBW, extremely LBW; PMA, postmenstrual age; PCA, postchronological age; VLBW, very LBW; CUG, catch-up growth; OR, odds ratio; $\mathrm{BMI}$, body mass index; aOR, adjusted odds ratio; CA, corrected age; PGF, postnatal growth failure; EUGR, extrauterine growth restriction; HM, human milk; NICU, neonatal intensive care unit; UHM, unfortified human milk; FHM, fortified human milk; PF, preterm formula-fed. 
growth (defined as below the 10th percentile of weight) using the KNGC was $33 \%$ at 24 months, $26 \%$ at 36 months, $32 \%$ at 48 months, and $36 \%$ at 60 months of age. ${ }^{28)}$ Compared to our data, the incidence of growth under the 10 th percentile at 1 year of age was $40.9 \%$ of 284 patients in China, while the NICHD in the United States indicated that $40 \%$ of patients still have a weight, length, and $\mathrm{HC}$ less than the 10 th percentile at $18-22$ months. ${ }^{13)}$

Although limited long-term data exist, many studies agree that, despite a period of catch-up growth, VLBW infants achieve retarded growth later in life. ${ }^{29)} \mathrm{A}$ study in the Netherlands revealed that VLBW infants remain shorter and lighter at age 19 years than non-VLBW infants. ${ }^{30)}$ Accordingly, at age 20 years, former VLBW infants were twice as likely as normal birth weight infants to have a short stature below the $3 \mathrm{rd}$ percentile. ${ }^{31)}$ Studies also suggest that compromised growth may result in a different body composition and lead to adverse health outcomes later in life. ${ }^{32)}$ Thus, catch-up growth in VLBW infants should be monitored after discharge.

The weight growth pattern from birth to 36 months of age showed significant differences between SGA and non-SGA infants and between VLBW infants and extremely low birth weight (ELBW) infants in the KNN study. ${ }^{27}$ Similarly, very preterm and SGA infants in Denmark showed a catch-up growth in weight and height at 6 years of age; however, they reached a significantly lower mean $z$ score than AGA children. ${ }^{33)}$

Growth is influenced by various factors, including comorbidities and sex. ${ }^{9,21)}$ From the NHIS database, hyaline membrane disease, patent ductus arteriosus, intraventricular hemorrhage, sepsis, and bronchopulmonary dysplasia (BPD) significantly increased the risk of having a weight less than the 10th percentile of normal at 60 months of age. ${ }^{28)}$ In particular, infants with BPD reportedly showed an increased risk of growth failure after discharge of 30\%-67\%. This finding is consistent with the result as an odds ratio (OR) of 2.18 at 18-24 months from the KNN study and OR of 1.50 at 60 months from the NHIS study.27,28) In a previous large-scale cohort study, infection in ELBW infants affected growth failure in weight and $\mathrm{HC}$ at both 36 weeks and 18-22 months of corrected age. ${ }^{26)}$ In Korea, infants with sepsis showed growth failure in weight $(\mathrm{OR}, 1.43)$ and $\mathrm{HC}(\mathrm{OR}$, 1.33). ${ }^{28)}$ In accordance with a previous study, infants with periventricular leukomalacia (PVL) had a relatively small HC (OR, $1.91)$ at 60 months of age. Knowing an infant's perinatal history, reducing the morbidity rate during admission, and performing regular check-ups after discharge can reduce the rate of growth failure.

\section{Postnatal growth of preterm infants by preschool age, adolescence, and adulthood}

Various studies have analyzed long-term growth patterns in premature infants using various definitions of poor growth and growth parameters (Table 2). Catch-up growth occurred mainly during the early neonatal period before 24 months and before discharge ${ }^{33,34)}$; however, the gains did not always continue over time. In the NHIS study of 430,541 infants covering $99 \%$ of national births in 2013, significant differences were noted in height, weight, and HC, respectively, according to age at health check-up, birth weight group, and combination of age and birth weight. ${ }^{35)}$ The lower birth weight group showed lower catch-up growth, even at 60 months. The mean weight, height, and HC percentiles were persistently below 40 among low birth weight and VLBW infants. ${ }^{35)}$ The full-term group had greater heights than the preterm group at 8 years of age when the healthy preterm and mid-preterm groups caught up. A systematic review of growth patterns and body composition among ELBW neonates stated that, despite catch-up growth, their weight, height, and HC growths remained retarded into adulthood. . $93,36,37)^{2}$

Pre- or full-term born SGA children were shorter and lighter until 3 years of age than AGA children. ${ }^{34,38-41)}$ The growth velocity ofSGA children was significantly higher than that of AGA children in the first 2 years of life. ${ }^{39)}$ In a single-center study in Korea, 29\% of SGA, 33\% of severe SGA ( $<3$ rd percentile), and $36.4 \%$ of moderate SGA (3rd-10th percentile) infants did not reach catch-up growth for weight goals at 24 months of PCA. ${ }^{15,42)}$ In a Swedish population cohort study, SGA moderate preterm (32-35 weeks) infants were shorter and lighter throughout the 5 -year follow-up and the association was stronger in SGA infants at birth. ${ }^{43)}$ The SGA group was still shorter and lighter at 12 years of age. ${ }^{40)}$

Nutrition is also a factor contributing to the growth of preterm infants; however, limited information is available on what it involves. Unfortified human milk-fed infants demonstrated slower catch-up growth that was extended until 6 years of age. Rapid weight growth was most pronounced shortly after discharge, especially in preterm formula-fed infants. ${ }^{33)}$

\section{Growth and development}

The correlations between growth and development revealed using various neurodevelopmental assessments in preterm infants are presented in Table 3. Although most studies focused on extremely preterm infants or VLBW infants, ${ }^{36,44,45)}$ even moderate preterm $\left(32^{+0}-33^{+6}\right.$ weeks' gestational age) or late-preterm $\left(34^{+0}-36^{+6}\right.$ weeks' gestational age) infants were at increased risk of poor neurodevelopmental outcomes. ${ }^{46-48}$ Being born preterm and SGA increased the risk of adverse developmental outcomes. 49,50)

In accordance with other studies, from the NHIS study, infants with poor weight, height, and $\mathrm{HC}$ growth were at an increased risk of suspected developmental delay at 60 months of age. ELBW infants were more likely to have a suspected developmental delay $(\mathrm{OR}, 5.05)$ than infants with a birth weight of 2,500-4,500 g. ${ }^{35)}$ According to Korean retrospective cohort studies, $\mathrm{HC}$ at 4 months of PCA was related to favorable neurodevelopmental outcomes at 18 months of PCA, while an HC growth spurt between a postmenstrual age of 35 weeks and a PCA of 4 months is beneficial for preterm AGA infants. ${ }^{34)}$ Catch-up growth of body 
Table 3. Overview of included studies on growth factors related to long-term infant development

\begin{tabular}{|c|c|c|c|c|c|c|c|}
\hline Study & $\begin{array}{l}\text { Study design/ } \\
\text { country }\end{array}$ & $\begin{array}{l}\text { Characteristics: } \\
\text { Number, GA/BW, } \\
\text { SGA/AGA }\end{array}$ & $\begin{array}{l}\text { Age at } \\
\text { follow-up }\end{array}$ & $\begin{array}{l}\text { Measure- } \\
\text { ment }\end{array}$ & $\begin{array}{l}\text { Age at } \\
\text { developmental } \\
\text { test }\end{array}$ & $\begin{array}{l}\text { Neurodevelop- } \\
\text { mental } \\
\text { assessment }\end{array}$ & Main results \\
\hline $\begin{array}{l}\text { Han et al. }{ }^{28)} \\
2021\end{array}$ & $\begin{array}{l}\text { Retrospective, } \\
\text { Korea }\end{array}$ & $\begin{array}{l}2,961 \\
\mathrm{BW}<1,500 \mathrm{~g}\end{array}$ & $\begin{array}{l}\text { 4-6, 9-12, 18- } \\
24,30-36 \\
42-48 \text { and } \\
54-60 \\
\text { months }\end{array}$ & HT, WT, HC & 54-60 months & K-DST & $\begin{array}{l}\text { Poor growth at } 60 \text { months of age showed } \\
\text { significantly poor developmental outcomes. } \\
\text { Children with PVL had small HC (OR, 1.91) and } \\
\text { poor developmental screening results (OR, } \\
\text { 2.89). }\end{array}$ \\
\hline $\begin{array}{l}\text { Yoon et al. } \\
2021\end{array}$ & $\begin{array}{l}\text { Retrospective, } \\
\text { Korea }\end{array}$ & $\begin{array}{l}430,541 \\
\text { BW subgroup; } \\
<1,000 \mathrm{~g} \\
1,000-1,499 \mathrm{~g} \\
1,500-1,999 \mathrm{~g} \\
2,000-2,499 \mathrm{~g} \\
2,500-4,500 \mathrm{~g}\end{array}$ & $\begin{array}{l}4-6,9-12,18- \\
24,30-36 \\
42-48, \text { and } \\
54-60 \\
\text { months }\end{array}$ & HT, WT, HC & 54-60 months & K-DST & $\begin{array}{l}\text { Increased risk of poor developmental results at } \\
60 \text { months in the infants with poor WT, HT, and } \\
\mathrm{HC} \text { growth. Infants with poor HC at } 60 \text { months } \\
\text { of age had poor developmental results (OR, } \\
\text { 1.81) }\end{array}$ \\
\hline $\begin{array}{l}\text { Song et } \text { al. }^{34)} \\
2020\end{array}$ & $\begin{array}{l}\text { Retrospective, } \\
\text { Korea }\end{array}$ & $\begin{array}{l}122 \\
\text { BW }<1,500 \text { g or } \\
\text { GA<32 weeks, } \\
\text { SGA 29/AGA } 93\end{array}$ & $\begin{array}{l}\text { PMA } 35 \\
\text { weeks, 4, } 18 \\
\text { months PCA }\end{array}$ & HT, WT, HC & 18 Months CA & BSID III & $\begin{array}{l}\mathrm{HC} \text { at } 4 \text { months CA was an important factor of } \\
\text { favorable neurodevelopmental outcomes, and } \\
\mathrm{HC} \text { growth spurt between PMA } 35 \text { weeks and } \\
4 \text { months CA in preterm AGAs }\end{array}$ \\
\hline $\begin{array}{l}\text { Sohn et al. } \\
2016\end{array}$ & $\begin{array}{l}\text { Retrospective, } \\
\text { Korea }\end{array}$ & $\begin{array}{l}107 \\
<32 \text { Weeks GA or } \\
\text { BW }<1,500 \mathrm{~g}\end{array}$ & $\begin{array}{l}\text { 8, } 18 \text { Months } \\
\text { CA }\end{array}$ & HT, WT, HC & 18 Months CA & BSID III & $\begin{array}{l}\text { Appropriate HT at birth was significantly asso- } \\
\text { ciated with optimal cognitive development. CUG } \\
\text { for HT was related to cognitive development, } \\
\text { while CUG of HC was related to both cognitive } \\
\text { and motor development. }\end{array}$ \\
\hline $\begin{array}{l}\text { Dotinga et al. }{ }^{54)} \\
2019\end{array}$ & $\begin{array}{l}\text { Prospective, } \\
\text { Netherlands }\end{array}$ & $\begin{array}{l}234 \\
32-36 \text { Weeks GA }\end{array}$ & 1, 4, 7 Years & HT, WT, HC & 7 Years & $\begin{array}{l}\text { WISC. 3rd: IQ } \\
\text { NTBC AVLT } \\
\text { MABC }\end{array}$ & $\begin{array}{l}\text { Poorer growth in the first } 7 \text { years is associated } \\
\text { with poorer neuropsychological functioning. }\end{array}$ \\
\hline $\begin{array}{l}\text { Egashira et al. }^{64)} \\
2019\end{array}$ & $\begin{array}{l}\text { Prospective, } \\
\text { Japan }\end{array}$ & $\begin{array}{l}280 \\
\text { VLBW infants }\end{array}$ & 40 Weeks CA & HT, WT, HC & 3 Years & KSPD & $\begin{array}{l}\text { A longer HT and larger HC at term were important } \\
\text { indicators that influenced better psychomotor } \\
\text { development in VLBW infants at } 3 \text { years of age. }\end{array}$ \\
\hline $\begin{array}{l}\text { Takeuchi et al. }{ }^{57)} \\
2019\end{array}$ & $\begin{array}{l}\text { Prospective, } \\
\text { Japan }\end{array}$ & $\begin{array}{l}1,667 \\
\text { Preterm }<37 \\
\text { weeks, SGA }\end{array}$ & 2 Years CA & HT & 5.5, 8 Years & $\begin{array}{l}\text { Questionnaire at } \\
5.5 \text { years } \\
\text { CBCL at } 8 \text { years }\end{array}$ & $\begin{array}{l}\text { Preterm SGA children without CUG at } 2 \text { years } \\
\text { were at increased risk for behavioral problems, } \\
\text { including inattention symptoms, from preschool } \\
\text { age to school age. }\end{array}$ \\
\hline $\begin{array}{l}\text { Taine et al. } \\
2018\end{array}$ & $\begin{array}{l}\text { Systematic } \\
\text { review }\end{array}$ & $\begin{array}{l}\text { Small }(\leq 30) \\
\text { 32-36 weeks GA } \\
\text { or SGA term }\end{array}$ & $\begin{array}{l}\text { From birth to } \\
\text { age } 3 \text { years }\end{array}$ & $\begin{array}{l}\text { HT, WT, } \\
\text { HC, BMI }\end{array}$ & 3-26 Years & $\begin{array}{l}\mathrm{IQ} \\
\mathrm{CBCL}, \mathrm{BSID} \|\end{array}$ & $\begin{array}{l}\text { Positive association with early postnatal growth } \\
\text { (first } 6 \text { months) }\end{array}$ \\
\hline $\begin{array}{l}\text { Raaijmakers } \\
\text { et al. }^{36)} 2017\end{array}$ & $\begin{array}{l}\text { Prospective, } \\
\text { Belgium }\end{array}$ & $\begin{array}{l}140 \\
B W<1,000 \mathrm{~g}\end{array}$ & $\begin{array}{l}9,24 \text { Months, } \\
11 \text { years }\end{array}$ & HT, WT, HC & $\begin{array}{l}24 \text { Months } C A \\
11 \text { years }\end{array}$ & $\begin{array}{l}\text { BSID-II-NL } \\
\text { Wechsler Non- } \\
\text { Verbal Test }\end{array}$ & $\begin{array}{l}\text { ELBW children had worse neurocognitive testing } \\
\text { results with an average IQ at } 11 \text { years. CUG was } \\
\text { not associated with neurocognitive perfor- } \\
\text { mance. }\end{array}$ \\
\hline $\begin{array}{l}\text { Sammallahti } \\
\text { et al. }^{52)} 2017\end{array}$ & $\begin{array}{l}\text { Prospective, } \\
\text { Finland }\end{array}$ & $\begin{array}{l}108 \\
34-36 \text { Weeks GA }\end{array}$ & $\begin{array}{l}\text { 5, } 20 \text { Months } \\
\text { CA, and } 56 \\
\text { months }\end{array}$ & HT, WT, HC & 24-26 Years & $\begin{array}{l}\text { WAIS-III: } \\
\text { Wechsler } \\
\text { Memory Scale- } \\
\text { III, Bohnen } \\
\text { version of the } \\
\text { Stroop test, } \\
\text { Grade point } \\
\text { average }\end{array}$ & $\begin{array}{l}\text { Faster growth in WT and HC from birth to } 5 \\
\text { months CA is associated with higher IQ and } \\
\text { better executive functioning in adulthood and } \\
\text { higher GPA. }\end{array}$ \\
\hline $\begin{array}{l}\text { Sicard et al. } \\
2017\end{array}$ & $\begin{array}{l}\text { Prospective, } \\
\text { France }\end{array}$ & $\begin{array}{l}4,046 \\
\leq 34 \text { Weeks GA }\end{array}$ & $\begin{array}{l}\text { Hospital } \\
\text { discharge }\end{array}$ & $\mathrm{HC}$ & 2 Years CA & & $\begin{array}{l}\mathrm{HC} \text { at birth and } \mathrm{HC} z \text { score between birth and } \\
\text { discharge are associated to neurodevelop- } \\
\text { mental outcome at } 2 \text { years }\end{array}$ \\
\hline $\begin{array}{l}\text { Ghods et al. } \\
2011\end{array}$ & $\begin{array}{l}\text { Retrospective, } \\
\text { Austria }\end{array}$ & $\begin{array}{l}173 \\
\text { VLBW }\end{array}$ & $\begin{array}{l}\text { 3, 6. 9. } 12 ., 24 \\
\text { Months CA } \\
\text { and 40, 54, } \\
66 \text { months }\end{array}$ & $\mathrm{HC}$ & 2 Years & $\begin{array}{l}\text { Neuromotor } \\
\text { assessments, } \\
\text { BSID ॥ }\end{array}$ & $\begin{array}{l}\text { Most HC catch-up occurred between birth and } 3 \\
\text { months CA. There is a close relation between } \\
\text { HC growth and neurodevelopmental outcome. }\end{array}$ \\
\hline $\begin{array}{l}\text { Franz et al. }{ }^{44)} \\
2009\end{array}$ & $\begin{array}{c}\text { Prospective, } \\
\text { Germany }\end{array}$ & $\begin{array}{l}219 \\
<30 \text { Weeks GA and } \\
\text { BW }<1,500 \mathrm{~g}\end{array}$ & At discharge & WT, HC & 5.4 Years & $\begin{array}{l}\text { KABC test } \\
\mathrm{CP}\end{array}$ & $\begin{array}{l}\text { Motor development was associated with growth } \\
\text { from birth to discharge. Cognitive develop- } \\
\text { ment was associated with BW, early neonatal } \\
\text { WT gain, and postdischarge HC growth. }\end{array}$ \\
\hline $\begin{array}{l}\text { Cheong et al. }{ }^{45)} \\
2008\end{array}$ & $\begin{array}{c}\text { Prospective, } \\
\text { Australia }\end{array}$ & $\begin{array}{l}227 \\
<30 \text { Weeks GA or } \\
\text { BW }<1,250 \mathrm{~g}\end{array}$ & 1,2 Years CA & WT, HC & 2 Years CA & BSID ॥ & $\begin{array}{l}\text { Poor HC growth becomes more evident by } 2 \\
\text { years and is associated with poor neurode- } \\
\text { velopmental outcome and cerebral palsy. }\end{array}$ \\
\hline
\end{tabular}

GA, gestational age; BW, birth weight; SGA, small for gestational age; AGA, appropriate for gestational age; BW, birth weight; HT, height; WT, weight; HC, head circumference; K-DST, Korean Developmental Screening Test; PVL, periventricular leukomalacia; OR, odds ratio; PMA, postmenstrual age; BSID, Bayley Scale of Infant Development; ELBW, extremely low birth weight; CA, corrected age; WISC, Wechsler Intelligence Scale for Children; IQ, intelligence quotient; NTBC, Neuropsychological Test Battery for Children; AVLT, Auditory Verbal Learning Test; BMI, body mass index; MABC, Movement Assessment Battery for Children; VLBW, very low birth weight; KSPD, Kyoto Scale of Psychological Development (Postural-Motor/Cognitive-Adaptive/Language-Social); CUG, catch-up growth; CBCL, Child Behavior Checklist; BMI, body mass index; WAIS, Wechsler Adult Intelligence Scale; KABC, Kaufman Assessment Battery for Children; CP, cerebral palsy. 
length was related to cognitive development, while catch-up growth of $\mathrm{HC}$ was related to both cognitive and motor development. ${ }^{51)}$ The period and indices differ between SGA and AGA infants, so they should be monitored differently. ${ }^{34)}$ Using multiple regression analysis to predict a risk factor for poor developmental outcomes at the age of 60 months, PVL (OR, 2.89), restricted $\mathrm{HC}$ growth $(\mathrm{OR}, 2.36)$, and restricted height growth $(\mathrm{OR}, 2.42)$ were confirmed. ${ }^{28)}$

Growth in the early postnatal period affectsneurodevelopmental outcomes at school age and adolescence. ${ }^{36,52)}$ Even during adulthood, psychological and behavioral problems are increased in the poor growth group, ${ }^{53)}$ and all height, weight, and $\mathrm{HC}$ growth parameters are related to developmental outcomes ${ }^{54)}$; however, the association between $\mathrm{HC}$ and neurodevelopment was more closely examined. ${ }^{34,45,51,55,56)}$ Brain size at term-equivalent age was associated with brain tissue volumes on magnetic resonance imaging. ${ }^{45)}$ Poor postnatal head growth in preterm infants becomes more evident by 2 years and is strongly associated with poor neurodevelopmental outcomes and cerebral palsy. Earlier catch-up HC growth was more critical for neurodevelopment than catch-up weight and length growth. ${ }^{51)}$

In a Japanese population study, SGA infants with poor postnatal growth were at risk for attention problems throughout preschool to school age. Twenty-six percent of preterm SGA infants failed to catch up. SGA children lacking catch-up growth were more likely to be unable to listen without fidgeting (OR, $2.51)$ and unable to focus on a task (OR, 2.66) than non-SGA children at 5.5 years of age. Furthermore, SGA children lacking catch-up growth were at a significant risk of inattention at 8 years of age. In contrast, the SGA and catch-up groups were not at increased risk of attention problems or delinquent/aggressive behaviors. ${ }^{57)}$ In a Brazilian cohort study, preterm infants born with IUGR were at increased risk of motor delays. ${ }^{58)}$ Thus, children born preterm and SGA, especially those lacking catch-up growth, should be monitored cautiously.

\section{Conclusion}

Recent improvements in preterm survival have shifted the focus on preterm infants toward improving their quality of life by monitoring their growth and development. In Korea, preterm infants still show differences in growth and development until preschool age. Thus, careful monitoring and early intervention are required.

\section{Footnotes}

Conflicts of interest: No potential conflict of interest relevant to this article was reported.

ORCID:

So Jin Yoon @ https://orcid.org/0000-0002-7028-7217
Joohee Lim @ https://orcid.org/0000-0003-4376-6607

Soon Min Lee @ https://orcid.org/0000-0003-0174-1065

\section{References}

1. Lubchenco LO, Hansman C, Dressler M, Boyd E. Intrauterine growth as estimated from liveborn birth-weight data at 24 to 42 weeks of gestation. Pediatrics 1963;32:793-800.

2. Olsen IE, Groveman SA, Lawson ML, Clark RH, Zemel BS. New intrauterine growth curves based on United States data. Pediatrics 2010;125: e214-24.

3. Bertino E, Spada E, Occhi L, Coscia A, Giuliani F, Gagliardi L, et al. Neo natal anthropometric charts: the Italian neonatal study compared with other European studies. J Pediatr Gastroenterol Nutr 2010;51:353-61.

4. Greer CF. Intrauterine growth as estimated from liveborn birth-weight data at 24 to 42 weeks of gestation, by Lula O. Lubchenco et al, Pediatrics, 1963;32:793-800. Pediatrics 1998;102(1 Pt 2):237-9.

5. Fenton TR, Nasser R, Eliasziw M, Kim JH, Bilan D, Sauve R. Validating the weight gain of preterm infants between the reference growth curve of the fetus and the term infant. BMC Pediatrics 2013;13:92.

6. Fenton TR, Kim JH. A systematic review and meta-analysis to revise the Fenton growth chart for preterm infants. BMC Pediatrics 2013;13:59.

7. Villar J, Ismail LC, Victora CG, Ohuma EO, Bertino E, Altman DG, et al. International standards for newborn weight, length, and head circumference by gestational age and sex: the Newborn Cross-Sectional Study of the INTERGROWTH-21st Project. Lancet 2014;384:857-68.

8. Sankilampi U. One size may not fit all when it comes to growth references for preterm infants. Acta Paediatr 2016;105:228-9.

9. Kuczmarski RJ, Ogden CL, Guo SS, Grummer-Strawn LM, Flegal KM, Mei Z, et al. 2000 CDC Growth Charts for the United States: methods and development. Vital Health Stat 11 2002;(246):1-190.

10. de Onis M. Update on the implementation of the WHO child growth standards. World Rev Nutr Diet 2013;106:75-82.

11. Kim JH, Yun S, Hwang SS, Shim JO, Chae HW, Lee YJ, et al. The 2017 Korean National Growth Charts for children and adolescents: development, improvement, and prospects. Korean J Pediatr 2018;61:135-49.

12. Fenton TR, Chan HT, Madhu A, Griffin IJ, Hoyos A, Ziegler EE, et al. Preterm infant growth velocity calculations: a systematic review. Pediatrics 2017;139:e20162045

13. Dusick AM, Poindexter BB, Ehrenkranz RA, Lemons JA. Growth failure in the preterm infant: can we catch up? Semin Perinatol 2003;27:302-10.

14. Griffin IJ, Tancredi DJ, Bertino E, Lee HC, Profit J. Postnatal growth failure in very low birth weight infants born between 2005 and 2012. Arch Dis Child Fetal Neonatal Ed 2016;101: F50-5.

15. Park JS, Han J, Shin JE, Lee SM, Eun HS, Park MS, et al. Postdischarge growth assessment in very low birth weight infants. Korean J Pediatr 2017; 60:64-9.

16. Kim ES, Sohn JA, Lee EH, Choi EJ, Lee HJ, Lee JA, et al. Extrauterine growth restriction in very low birth weight infants. J Korean Soc Neonatol 2010;17:53-63.

17. Lee SM, Kim N, Namgung R, Park M, Park K, Jeon J. Prediction of postnatal growth failure among very low birth weight infants. Sci Rep 2018;8: 3729.

18. Fenton TR, Cormack B, Goldberg D, Nasser R, Alshaikh B, Eliasziw M, et al. "Extrauterine growth restriction" and "postnatal growth failure" are misnomers for preterm infants. J Perinatol 2020;40:704-14.

19. Marks KA, Reichman B, Lusky A, Zmora E. Fetal growth and postnatal growth failure in very-low-birthweight infants. Acta Paediatr 2006;95: 236-42.

20. Lima PA, Carvalho M, Costa AC, Moreira ME. Variables associated with extrauterine growth restriction in very low birth weight infants. J Pediatr (Rio J) 2014;90:22-7.

21. Senterre T, Rigo J. Optimizing early nutritional support based on recent recommendations in VLBW infants and postnatal growth restriction. J Pediatr Gastroenterol Nutr 2011;53:536-42. 
22. Embleton NE, Pang N, Cooke RJ. Postnatal malnutrition and growth retardation: an inevitable consequence of current recommendations in preterm infants? Pediatrics 2001;107:270-3.

23. Pilling EL, Elder CJ, Gibson AT. Growth patterns in the growth-retarded premature infant. Best Pract Res Clin Endocrinol Metab 2008;22:447-62.

24. Shim JW, Whang JH, Choi CW, Chang YS, Park WS. Failure to thrive of very low birth weight infants up to corrected 18 months of age. J Korean Soc Neonatol 2003;10:115-24.

25. Lim JW, Jun NL, Kim KA, Kim AR, Kim KS, Pi SY. Postnatal catch-up growth of very low birth weight infants. J Korean Soc Neonatol 2002;9:111.

26. Ma TH, Kim KA, Ko SY, Lee YK, Shin SM. Catch-up growth and development of very low birth weight infants. Korean J Pediatr 2006;49:29-33.

27. Lim JH, Yoon SJ, Han JH, Shin JE, Lee SM, Eun HS, et al. Growth failure of very low birth weight infants during the first 3 years: a Korean Neonatal Network. PLoS One 2021;16:e0259080.

28. Han JH, Yoon SJ, Lim JH, Shin JE, Song IG, Lee SM, et al. The impact of neonatal morbidities on child growth and developmental outcome in very low birthweight infants: nationwide cohort study. Eur J Pediatr 2021 Jul 8. https://doi.org/10.1007/s00431-021-04177-x. [Epub].

29. Van de Pol C, Allegaert K. Growth patterns and body composition in former extremely low birth weight (ELBW) neonates until adulthood: a systematic review. Eur J Pediatr 2020;179:757-71.

30. Hollanders JJ, van der Pal SM, van Dommelen P, Rotteveel J, Finken MJJ. Growth pattern and final height of very preterm vs. very low birth weight infants. Pediatr Res 2017;82:317-23.

31. Hack M, Flannery DJ, Schluchter M, Carter L, Borawski E, Klein N. Outcomes in young adulthood for very-low-birth-weight infants. NEngl J Med 2002;346:149-57.

32. Morrison KM, Ramsingh L, Gunn E, Streiner D, Van Lieshout R, Boyle $\mathrm{M}$, et al. Cardiometabolic health in adults born premature with extremely low birth weight. Pediatrics 2016;138:e20160515.

33. Toftlund LH, Halken S, Agertoft L, Zachariassen G. Catch-up growth, rapid weight growth, and continuous growth from birth to 6 years of age in very-preterm-born children. Neonatology 2018;114:285-93.

34. Song IG, Kim EK, Cho H, Shin SH, Sohn JA, Kim HS. Differential effect of growth on development between aga and SGA preterm infants. Int J Environ Res Public Health 2020;17:3022.

35. Yoon SJ, Lim J, Han JH, Shin JE, Lee SM, Eun HS, et al. Identification of growth patterns in low birth weight infants from birth to 5 years of age: nationwide Korean cohort study. Int J Environ Res Public Health 2021; 18:1206.

36. Raaijmakers A, Jacobs L, Rayyan M, van Tienoven TP, Ortibus E, Levt. chenko E, et al. Catch-up growth in the first two years of life in extremely low birth weight (ELBW) infants is associated with lower body fat in young adolescence. PLoS One 2017;12:e0173349.

37. Rowe DL, Derraik JGB, Robinson E, Cutfield WS, Hofman PL. Preterm birth and the endocrine regulation of growth in childhood and adolescence. Clin Endocrinol 2011;75:661-5.

38. Nobile S, Marchionni P, Carnielli VP. Neonatal outcome of small for gestational age preterm infants. Eur J Pediatr 2017;176:1083-8.

39. Olbertz DM, Mumm R, Wittwer-Backofen U, Fricke-Otto S, Pyper A, Otte J, et al. Identification of growth patterns of preterm and small-forgestational age children from birth to 4 years - do they catch up? J Perinat Med 2019;47:448-54.

40. Sullivan MC, McGrath MM, Hawes K, Lester BM. Growth trajectories of preterm infants: birth to 12 years. J Pediatr Health Care 2008;22:83-93.

41. Kim S, Choi Y, Lee S, Ahn MB, Kim SH, Cho WK, et al. Growth patterns over 2 years after birth according to birth weight and length percentiles in children born preterm. Ann Pediatr Endocrinol Metab 2020;25:163-8.

42. Huh J, Kwon JY, Kim HR, Lee EH, Rhie YJ, Choi BM, et al. Comparison of postnatal catch-up growth according to definitions of small for gestational age infants. Korean J Pediatr 2018;61:71-7.

43. Lindström L, Ahlsson F, Lundgren M, Bergman E, Lampa E, Wikström AK. Growth patterns during early childhood in children born small for gestational age and moderate preterm. Sci Rep 2019;9:11578.

44. Franz AR, Pohlandt F, Bode H, Mihatsch WA, Sander S, Kron M, et al. In- trauterine, early neonatal, and postdischarge growth and neurodevelopmental outcome at 5.4 years in extremely preterm infants after intensive neonatal nutritional support. Pediatrics 2009;123:e101-9.

45. Cheong JLY, Hunt RW, Anderson PJ, Howard K, Thompson DK, Wang $\mathrm{HX}$, et al. Head growth in preterm infants: correlation with magnetic resonance imaging and neurodevelopmental outcome. Pediatrics 2008; 121:e1534-40.

46. Hack M, Breslau N, Weissman B, Aram D, Klein N, Borawski E. Effect of very low birth weight and subnormal head size on cognitive abilities at school age. NEngl J Med 1991;325:231-7.

47. Connors JM, O'Callaghan MJ, Burns YR, Gray PH, Tudehope DI, Mohay $\mathrm{H}$, et al. The influence of growth on development outcome in extremely low birth weight infants at 2 years of age. J Paediatr Child Health 1999; 35:37-41.

48. Hintz SR, Kendrick DE, Stoll BJ, Vohr BR, Fanaroff AA, Donovan EF, et al. Neurodevelopmental and growth outcomes of extremely low birth weight infants after necrotizing enterocolitis. Pediatrics 2005;115:696703.

49. McGowan JE, Alderdice FA, Holmes VA, Johnston L. Early childhood development of late-preterm infants: a systematic review. Pediatrics 2011; 127:1111-24.

50. Heinonen K, Lahti J, Sammallahti S, Wolke D, Lano A, Andersson S, et al. Neurocognitive outcome in young adults born late-preterm. Dev Med Child Neurol 2018;60:267-74.

51. Sohn JA, Kim EK, Lee JA, Choi CW, Kim HS, Kim BI, et al. Neurodevelopmental outcome according to prenatal and postnatal growth patterns in preterm infants. Neonatal Med 2016;23:108-15.

52. Sammallahti S, Heinonen K, Andersson S, Lahti M, Pirkola S, Lahti J, et al. Growth after late-preterm birth and adult cognitive, academic, and mental health outcomes. Pediatr Res 2017;81:767-74.

53. Stathis SL, O'Callaghan M, Harvey J, Rogers Y. Head circumference in ELBW babies is associated with learning difficulties and cognition but not ADHD in the school-aged child. Dev Med Child Neurol 1999;41:375-80.

54. Dotinga BM, Eshuis MS, Bocca-Tjeertes IF, Kerstjens JM, Van Braeckel $\mathrm{KN}$, Reijneveld SA, et al. Longitudinal growth and neuropsychological functioning at age 7 in moderate and late preterms. Pediatrics 2016;138: e20153638.

55. Sicard M, Nusinovici S, Hanf M, Muller JB, Guellec I, Ancel PY, et al. Fetal and postnatal head circumference growth: Synergetic factors for neurodevelopmental outcome at 2 years of age for preterm infants. Neonatology 2017;112:122-9.

56. Ghods E, Kreissl A, Brandstetter S, Fuiko R, Widhalm K. Head circumference catch-up growth among preterm very low birth weight infants: effect on neurodevelopmental outcome. J Perinat Med 2011;39:579-86.

57. Takeuchi A, Yorifuji T, Hattori M, Tamai K, Nakamura K, Nakamura M, et al. Catch-up growth and behavioral development among preterm, smallfor-gestational-age children: a nationwide Japanese population-based study. Brain Dev 2019;41:397-405.

58. Rocha PRH, Saraiva MDCP, Barbieri MA, Ferraro AA, Bettiol H. As sociation of preterm birth and intrauterine growth restriction with child hood motor development: Brisa cohort, Brazil. Infant Behav Dev 2020; 58:101429.

59. Park HJ, Lee HY, Woo HK, Kim SN, Lee J, Yang HR, et al. et al. The usefulness of birth weight $\mathrm{z}$-score as a predictor of catch up growth in preterm infants. Neonatal Med 2015;22:142-9.

60. Ou-Yang MC, Sun Y, Liebowitz M, Chen CC, Fang ML, Dai W, et al. Accelerated weight gain, prematurity, and the risk of childhood obesity: a meta-analysis and systematic review. PLoS One 2020;15:e0232238.

61. Liao WL, Lin MC, Wang TM, Chen $\mathrm{CH}$. Risk factors for postdischarge growth retardation among very-low-birth-weight infants: a nationwide registry study in Taiwan. Pediatr Neonatol 2019;60:641-7.

62. Visuthranukul C, Abrams SA, Hawthorne KM, Hagan JL, Hair AB. Premature small for gestational age infants fed an exclusive human milkbased diet achieve catch-up growth without metabolic consequences at 2 years of age. Arch Dis Child Fetal Neonatal Ed 2019;104:F242-7.

63. Farooqi A, Hägglöf B, Sedin G, Gothefors L, Serenius F. Growth in 10to 12 -year-old children born at 23 to 25 weeks' gestation in the 1990s: a 
Swedish national prospective follow-up study. Pediatrics 2006;118:e145265.

64. Egashira T, Hashimoto M, Shiraishi TA, Shichijo A, Egashira M, Mizukami $\mathrm{T}$, et al. A longer body length and larger head circumference at term significantly influences a better subsequent psychomotor development in verylow-birth-weight infants. Brain Dev 2019;41:313-9.

65. Taine M, Charles MA, Beltrand J, Rozé JC, Léger J, Botton J, et al. Early postnatal growth and neurodevelopment in children born moderately preterm or small for gestational age at term: A systematic review. Paediatr Perinat Epidemiol 2018;32:268-80.

How to cite this article: Lim J, Yoon SJ, Lee SM. Growth patterns of preterm infants in Korea. Clin Exp Pediatr 2022;65: 1-9. https://doi.org/10.3345/cep.2021.00234 